\title{
Reasons for and against participation in studies of medicinal therapies for women with breast cancer: a debate
}

Gero Luschin $^{1 * \dagger}$, Marion Habersack ${ }^{2 \dagger}$ and Irmina-Anna Gerlich ${ }^{2}$

\begin{abstract}
Background: A special challenge for research studies of breast cancer among females is low patient participation rates. We compiled this systematic review to identify reasons why women with, or at high risk of, breast cancer do or do not participate in medicinal studies of breast cancer.

Method: A systematic literature search in the databases Cochrane Library, EMBASE, Medline, Pascal Biomed, ACP Journal Club and CINAHL, as well as searches through reference lists of relevant texts, was performed.

Results: Of 39 relevant full texts, ultimately, nine studies (1 qualitative, 8 quantitative) were included after applying the inclusion criteria. Despite a lack of data material, it was possible to identify various factors influencing women's willingness to participate in medicinal studies and group them into three categories: person-related, study-related, and physician-related.

Conclusion: Reasons for or against participation in studies of medicinal therapies by women with, or at high risk of, breast cancer are multi-dimensional, and should be considered when planning such studies to garner higher participation rates. For a more comprehensive picture of factors that affect participation, further studies in this field are recommended.
\end{abstract}

Keywords: Breast cancer, Trial participation, Literature, Review

\section{Background}

Recruitment of participants in breast cancer trials relative to the incidence of breast cancer patients is somewhat higher than in other cancer types, such as colorectal or lung cancer [1]. However, the number of participants in breast cancer trials is still rather low. Estimates of participation of adult persons in cancer studies is about $1.5-11 \%$ of the total number of newly diagnosed or incidental cases [1,2]. Low participation in studies can lead to under-representation, which, in turn, can result in an effect or a clinical effectiveness being shown as not significant [3] or in a failure to obtain theoretical data saturation [4]. Low participation rates in a study may also induce bias, whereby those enrolled do not represent the target population very well. The reason why a planned

\footnotetext{
*Correspondence: gero.luschin@gmail.com

† Contributed equally

${ }^{1}$ Medical University Graz, Auenbruggerplatz 14, 8036 Graz, Austria
}

Full list of author information is available at the end of the article sample size is not reached within the time frame can, among other things, depend on problems in recruiting participants [5]. Research studies, grouped in reviews, have investigated possible barriers to cancer patients' participation in clinical studies [6-8]. Among these barriers are, for example, randomization, preferences for a certain therapy, degree of knowledge or additional effort in travel $[6,7]$.

In all of these studies however, patients with different cancer types were combined; for example, breast cancer, lung cancer and intestinal cancer, as well as various therapies.

To gain a better understanding of why especially female breast cancer patients frequently do not participate in clinical medicinal studies, a systematic review regarding this sensitive female patient group was conducted. 


\section{Method}

\section{Study type}

This review includes both qualitative and quantitative studies that discuss reasons and barriers or influencing factors for the participation of female breast cancer patients in medicinal studies. Clinical medicinal studies in this paper, are defined as studies with a variety of medical therapies, which may include, for example, chemotherapies, endocrine therapies and immune therapies within neo-adjuvant and adjuvant therapy [9].

\section{Search strategy}

In May 2011, a systematic literature search was carried out in the databases: Cochrane, EMBASE, Medline, Pascal Biomed, ACP Journal Club, and CINAHL. The following combination of MeSh-Terms and Keywords was chosen: \#1: cancer OR tumo* OR oncolog* OR neoplasms; \#2: willing* OR enrol* OR informed consent OR participat"; \#3: clinical and trial"; \#4: medica* or drug or pharma*; \#5: breast; \#6: \#1 AND \#2 AND \#3 AND \#4 AND \#5.

Articles were limited to those published in the last 10 years in German or English. When uncertainties regarding whether the content of the studies was suitable for this review occurred while screening study abstracts (or when articles did not have abstracts), the respective full texts were procured for further evaluation. To find additional relevant literature, the reference lists of the full texts were searched for possible articles.

\section{Selection criteria}

Inclusion criteria: studies that focused on participation or non-participation in clinical medicinal studies of adult women with breast cancer.

Exclusion criteria: studies that did not examine consent-competent female patients, did not focus on medications, investigated the effectiveness of medications, or did not refer to primary sources, study protocols and commentaries.

\section{Data evaluation}

Full texts found in the literature research were evaluated regarding methodical or theoretical rigor by means of the applicable quality checklist for quantitative or qualitative studies of the Alberta Heritage Foundation for Medical Research [10]; texts with values $<.75$ by these criteria were not used.

\section{Data analysis}

The following data were extracted from the respective full texts: objective, study type/design, method, number and characteristics of the participants, definition of the term "study participation," setting, and results. These extracted data were compared and categorized with regard to factors influencing participation (for and against see Table 1 and 2) in clinical medicinal studies of women, regardless of which research area they originally came from. This categorization was performed according to Mills et al., 2006 [7].

\section{Results}

After applying the selection criteria according to the title and abstract screening, 39 publications (of initially 3080 references) remained for further evaluation. Twelve publications were excluded as secondary literature, comments or protocols; 17 publications were excluded because their focus was not of interest (e.g., medicinal studies). One additional article was included from the reference lists. Two articles had to be excluded as they each had a quality score of $<0.75$. Ultimately, 9 publications met the inclusion criteria and were subjected to further analysis and evaluation (see Figure 1).

Eight of these nine included studies were quantitative [11-18]; only one was qualitative [19]. The summarized data extraction of the individual studies is found in Table 3 . The quality assessments performed, including comments, are depicted in Tables 4 and 5, according to research areas. Four of the studies were conducted in the United States $[12,13,17,19]$, two in Canada $[11,14]$, and the rest in Europe; in Germany [15], France [16] and Italy [18]. All of these articles have been published in English.

In the articles, a great variety of study designs were utilized as case-control [12], cohort [16] or randomized studies [17] (among others), where the design was not explicitly identified in most of them [11,13-15,18,19]. The prevalent method used to elicit women's reasons for or against participation in studies with medicinal therapies were questionnaires [11-13,15-18]. Most of the articles referred to investigations already performed, to identify the relevant reasons for consent or refusal to participate $[12,14,15,18,19]$. Three studies, though, used theoretical scenarios for the solicitation of reasons $[11,13,16]$. In one article, on the other hand, women were asked regarding their intent to participate in a currently active study [17].

The majority of the studies focused on chemotherapies $[11,12,15-17,19]$, whereas only one particularly referred to endocrine therapy [18], one to a new aromatase inhibitor, other endocrine therapy and chemotherapy [14], and another one generally to medicines [13].

Half of the studies addressed post-menopausal women, each with varying degrees of breast cancer risk [12,15,17-19], and half of the studies addressed women with invasive breast cancer $[11,13,14,16]$. The studies mainly investigated women with an average age of 53 
Table 1 Reasons for participation in medicinal studies

\begin{tabular}{|c|c|}
\hline Reasons for participation & Statistical output \\
\hline $\begin{array}{l}\text { Altruism (support of medical research and/or } \\
\text { helping other patients) }\end{array}$ & $\begin{array}{l}\text { Support of medical research or helping other people }(33 \%, n=8)[11] \text {; contribution to therapeutic } \\
\text { knowledge }(44 \%, n=116) \text { [18]; altruism in general }(50 \%, n=14)[19] \text {; non-participants felt bad } \\
\text { due to altruistic reasons as they themselves did not contribute to the study efforts ( } 39 \%, n=9) \\
{[19]}\end{array}$ \\
\hline $\begin{array}{l}\text { Wish for improvement (regarding own chances or } \\
\text { regular medical care) }\end{array}$ & $\begin{array}{l}\text { Improve the chances for breast cancer prevention }(P=0.033 ; \mathrm{OR}=3.16 ; 95 \% \mathrm{Cl}:[1.10-9.06])[12] \text {; a } \\
\text { regular medical care }(58 \%, \mathrm{n}=154)[18] \text {, wish for helping themselves }(50 \%, \mathrm{n}=14)[19]\end{array}$ \\
\hline $\begin{array}{l}\text { Concern of breast cancer or often thinking about } \\
\text { the topic of breast cancer }\end{array}$ & $\begin{array}{l}\text { Cancer thoughts }(P=0.002 ; \mathrm{OR}=2.30 ; 95 \% \mathrm{Cl}:[1.40-3.80])[17] \text {, strong concerns regarding breast } \\
\text { cancer }(P=0.01 ; \mathrm{OR}=0.15 ; 95 \% \mathrm{Cl}:[0.03-0.77])[18]\end{array}$ \\
\hline Physical condition & $\begin{array}{l}\text { Women with non-metastasized carcinoma vs. metastasized carcinoma }(\mathrm{RR}=2.80, P<0.01)[14] \\
\text { good-excellent vs. fair-poor health status }(P=0.05 ; \mathrm{OR}=1.47 ; 95 \% \mathrm{Cl}:[1.25-1.98])[17]\end{array}$ \\
\hline Age & $\begin{array}{l}49 \pm 10 \text { vs. } 54 \pm 11 \text { years }(\text { mean } \pm \text { SD) }(P<0.0001 ; \mathrm{OR}=1.05 ; 95 \% \mathrm{Cl}:[1.02-1.08])[17] \text {; under } 60 \\
\text { years }(P=0.003 ; \mathrm{OR}=0.40,95 \% \mathrm{Cl}:[0.22-0.73])[18]\end{array}$ \\
\hline Memory of close person(s) with breast cancer & $\begin{array}{l}21 \%(n=6) \text { valued their own breast cancer risk as low, but nevertheless participated in the study } \\
\text { out of respect or a memory of a close person who suffered from breast cancer [19] }\end{array}$ \\
\hline Readiness for treatment in a study & Nothing to lose by participating $(33 \% ; n=8)[11]$; general willingness $(60 \% ; n=160)[18]$ \\
\hline Acceptance of randomization & Acceptance of randomization $(P<0.001 ; \mathrm{OR}=4.6 ; 95 \% \mathrm{Cl}:[2.7-7.7])[16]$ \\
\hline No placebo & Placebo vs. no placebo $(\mathrm{RR}=0.80 ; P=0.05)[14]$ \\
\hline $\begin{array}{l}\text { Longer interval from diagnosis/surgery/end of } \\
\text { therapy until enrollment }\end{array}$ & $\begin{array}{l}\text { For non-metastatic trials: if the study protocol planned an interval of } 12 \text { weeks or longer between } \\
\text { diagnosis/op/end of therapy and recruiting in comparison to a shorter interval }(\mathrm{RR}=1.36 ; P< \\
\text { 0.01) [14] }\end{array}$ \\
\hline $\begin{array}{l}\text { Already decided once to participate in a medicinal } \\
\text { study }\end{array}$ & Already having decided to participate in a study $(P<0.001 ; \mathrm{OR}=5.0 ; 95 \% \mathrm{Cl}:[2.9-8.7])[16]$ \\
\hline Predominantly advantages through the study & $\begin{array}{l}\text { Perceived value of the trial }(P=0.020 ; \mathrm{OR}=2.92 ; 95 \% \mathrm{Cl} \text { : } 11.18-7.21])[12] \text {, predominant advantages } \\
\text { of the study }(50 \%, \mathrm{n}=14)[19]\end{array}$ \\
\hline Each treatment strategy seems helpful & Each of the treatments seems to be beneficial $(42 \% ; n=10)[11]$ \\
\hline Idea of receiving a better treatment & Idea to receive better treatment $(25 \% ; n=6)[11]$ \\
\hline Feeling, physicians must make decisions & Medical decision-making preferences $(P=0.045 ; \mathrm{OR}=2.2 ; 95 \% \mathrm{Cl}:[1.0-4.9])[16]$ \\
\hline $\begin{array}{l}\text { Feeling of not being able to reject physician's } \\
\text { suggestion }\end{array}$ & Unable to refuse the physician's suggestion ( $P=0.031$; OR $=1.8 ; 95 \% \mathrm{Cl}$ : [1.1-3.2]) [16] \\
\hline $\begin{array}{l}\text { Satisfaction with receiving information during } \\
\text { consultation with physician }\end{array}$ & $\begin{array}{l}\text { Satisfaction with communication processes }(P<0.001 \text {; or }=3.1 ; 95 \% \mathrm{Cl}:[1.5-7.8])[16] \text {, satisfaction } \\
\text { with the physician's explanations }(P<0.001 ; \mathrm{OR}=9.33 ; 95 \% \mathrm{Cl}:[4.04-21.55])[18]\end{array}$ \\
\hline $\begin{array}{l}\text { Receiving information regarding financial conflicts } \\
\text { of interest }\end{array}$ & $\begin{array}{l}\text { 61-72\% ( } n=614-724) \text { wish to receive information about financial conflicts of interest [13]. 61-84\% } \\
(n=614-845) \text { would participate in a medication study in spite of financial conflicts of interest [13] }\end{array}$ \\
\hline $\begin{array}{l}\text { Adequate medical expert knowledge or } \\
\text { qualification of the physician }\end{array}$ & Clinician expertise and qualifications $(P=0.012 ; \mathrm{OR}=4.9 ; 95 \% \mathrm{Cl}:[1.41-17.04])[12]$ \\
\hline
\end{tabular}

(range: 40-66 years) [11-18]. One study mainly included women in age groups 50-59, 60-69 and 70-79 years [19].

\section{Discussion and conclusions}

The various factors influencing participation in breast cancer medicinal research identified in the nine studies were placed by the authors into three categories: personrelated, physician-related and study-related.

The person-related category comprised health, psychosocial and demographic reasons. A younger age (demographic reason) was identified as a factor influencing willingness to participate $[15,17,18]$.

Regardless of whether study participants were younger or older, they frequently had high subjective perceptions of their risk of breast cancer $[16,18]$, although their objective risks, assessed according to Gail scores, in one of the two studies, were relatively low on average $[17,19,20]$. Another study also showed women who had participated in medication studies assessed their breast cancer risk subjectively much higher than women who had not participated, though both groups did not differ according to their Gail scores [19]. This suggests that, in future studies, subjective perceptions of risk should be addressed. Also, in ovarian cancer investigations, potential subjects' higher personal risk perception and concern raised the probability of making use of screening $[21,22]$. These results suggest that women's participation in such studies depends more on subjective risk than objective risk. Though subjective breast cancer risk in two studies in this review correlated with the women's willingness to participate $[17,19]$, in another medication study, women's participation was more likely when they were less personally concerned about breast cancer [18]; however, this last-mentioned study does not reveal whether relatives of the study participants had suffered from breast cancer or not, which could increase the subjects' concern, and thus interest, in participating in a medication study. One study showed women who had first and second degree relatives with breast cancer requested 
Table 2 Reasons against participation in medicinal studies

\begin{tabular}{|c|c|}
\hline Reasons for non-participation & Statistical output \\
\hline Inconspicuous mammography result & Inconspicuous result of a mammography $(42 \%, n=84)[15]$ \\
\hline Additional chronic and/or acute sickness & $\begin{array}{l}\text { Current chronic or acute sickness }(20 \%, n=40)[15] \text {, having a higher risk of developing other diseases than } \\
\text { breast cancer (more than } 50 \%, n>14)[19]\end{array}$ \\
\hline Skepticism towards clinical studies & General skepticism towards clinical studies $(2 \%, n=4)[15]$ \\
\hline $\begin{array}{l}\text { Feeling of becoming an "experiment" by } \\
\text { participating }\end{array}$ & The thought of being an experiment $(10 \%, n=3)[11]$ \\
\hline $\begin{array}{l}\text { Additional family problems or no family } \\
\text { support }\end{array}$ & Family problems $(5 \%, \mathrm{n}=9)[18]$ \\
\hline Fear of possible side effects & $\begin{array}{l}\text { Side effects }(14 \%, n=4)[11],(3 \%, n=6)[15], 31 \%(n=59)[18], 35 \%(n=8)[19], \text { willingness decreased } \\
\text { from } 72 \%(n=324) \text { to } 52 \% \text { after explanation of side effects, and to } 45 \% \text { after uterine cancer was } \\
\text { mentioned [17] }\end{array}$ \\
\hline Preference of a certain treatment form & $\begin{array}{l}\text { Preferences regarding chemotherapy }(21 \%, n=6)[11] \text {, not the same advantages as a menopausal hormone } \\
\text { replacement therapy }(22 \%, n=5)[19]\end{array}$ \\
\hline Additional time necessary & $\begin{array}{l}\text { Level of trial inconvenience regarding to the time requirements }(P=0.002 \text {, OR }=0.10,95 \% \mathrm{Cl}[0.02-0.44]) \\
{[12] \text {, need too much time for the study }(7 \%, n=14)[15] \text {, additional time and effort needed }(22 \%, n=5)} \\
{[19]}\end{array}$ \\
\hline Study lasts too long & Aversion to taking tamoxifen for 5 years $(14 \%, n=4)[11]$, study duration $(6 \%, n=11)[18]$ \\
\hline $\begin{array}{l}\text { Too far to travel from home to place of } \\
\text { study }\end{array}$ & Too far to travel from home to the examination center $(12 \%, \mathrm{n}=24)[15]$, distance $(4 \%, \mathrm{n}=8)[18]$ \\
\hline Randomization & $\begin{array}{l}\text { Aversion regarding the allotment of treatments in the study }(38 \%, n=11) \text { or regarding the randomization } \\
(17 \%, n=5)[11] \text {, randomization }(39 \%, n=9)[19]\end{array}$ \\
\hline Fear of medication abuse & Medication abuse $(33 \%, n=64)[18]$ \\
\hline $\begin{array}{l}\text { Incompatibility of own therapy and } \\
\text { study medication }\end{array}$ & Incompatibility of their hormone replacement therapy with the study medication $(22 \%, n=5)$ [19] \\
\hline $\begin{array}{l}\text { Concern of not receiving appropriate } \\
\text { therapy for oneself }\end{array}$ & Concern of receiving the appropriate treatment $(7 \%, \mathrm{n}=2)[11]$ \\
\hline $\begin{array}{l}\text { Not willing to lose control over personal } \\
\text { decisions }\end{array}$ & $\begin{array}{l}\text { Loss of control }(7 \%, \mathrm{n}=2)[11] \text {, women who refused showed preferences regarding personal decision } \\
\text { making }(72 \%) \text { versus women who accepted }(35 \%)(P<0.001)[16]\end{array}$ \\
\hline $\begin{array}{l}\text { Not willing to decide for oneself } \\
\text { regarding participation }\end{array}$ & Not want to make own decision because physician should decide $(10 \%, n=3)[11]$ \\
\hline Physician's advice not to participate & Physician counsel not to participate $(24 \%, n=46)[18]$ \\
\hline
\end{tabular}

information about the medication study twice as often as women who did not have this diagnosis among their relatives (OR 2.35, 95\% CI, 0.99-5.57)[15].

Studies show a negative correlation between the concern regarding breast cancer and satisfaction with the physician's consultation [23]. Nevertheless, satisfaction with physicians' consultation and communication processes (physicianrelated reason) was mentioned as reason for participation/ non-participation in medication studies $[16,18]$, indicating that patient-clinician relationships play a decisive role in patients' willingness to participate in a study.

Identification of potential differences in consultations in the medication studies was not possible $[11,13,16]$ because only one study reported the content of the conversations [17]. Therefore, not all women in the studies might have been informed about the same things. To avoid this distortion in future studies, the use and documentation of conversation manuals in these consultations seems advisable.

The main study protocol-related reason against participation was additional time needed $[12,18,19]$.
The randomization procedure was mentioned in two studies as reason against participation $[11,19]$; willingness for randomization was mentioned in one study as an influencing factor for participation [16]. In cancer research, lack of understanding of the principle of randomization has been researched as barrier to subject participation [24,25]. Another study showed that, among those who initially decided against participation in randomized studies, more than half ultimately consented to participation after they had received more detailed information regarding the randomization process [26]. Though this connection was not identifiable from studies in this review, our results showed that randomization could influence participation in medication studies. Informing potential study subjects of the reasons for randomization could therefore promote their participation.

Fear of possible side-effects (a treatment-related reason) was also frequently mentioned as reason for nonparticipation $[11,15,18,19]$, suggesting that the probabilities for possible side-effects should be explained extensively during recruitment. 

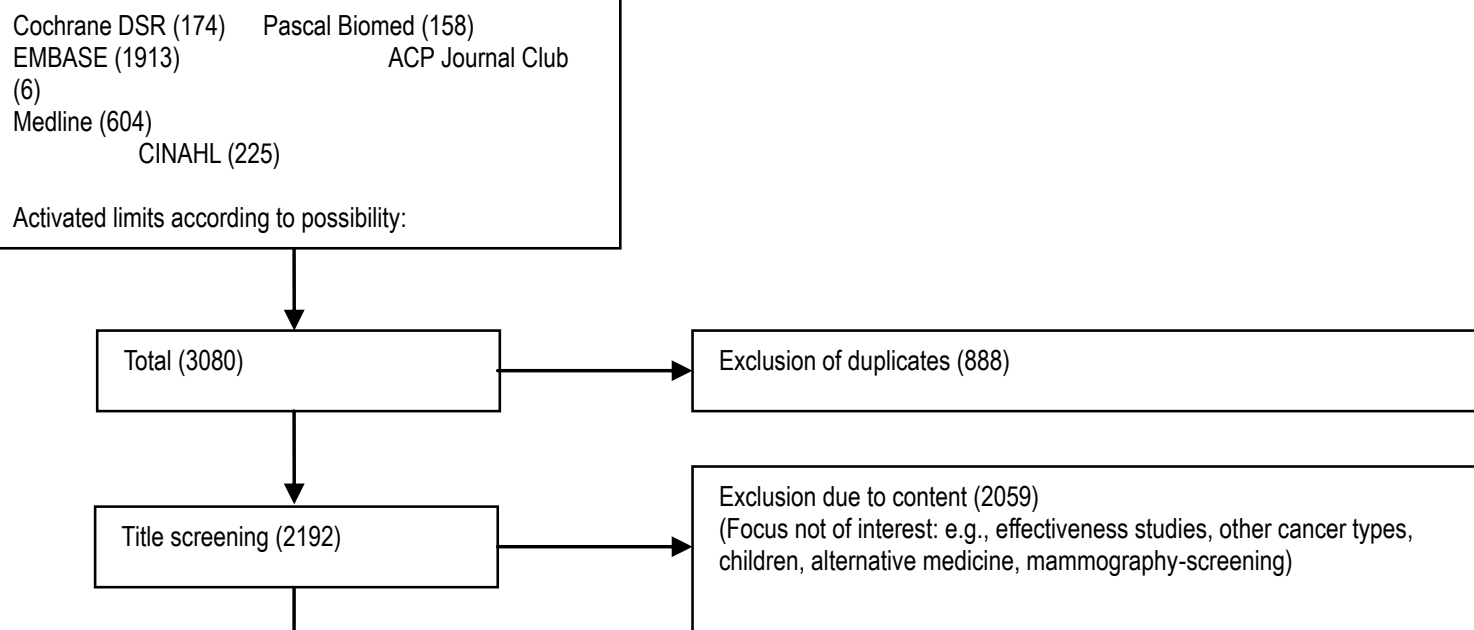

Exclusion due to content (94)

36 Effectiveness of medications/interventions/therapies/ procedures/breast care management

28 Focus /Target population not breast cancer patients

13 Other

10 Medical first sessions

7 Psycho-social: consequences of breast cancer/contentment studies

Exclusion due to content ( 30$)$

12 No primary source, comments, protocols,

17 Focus not of interest (e.g., cancer in general or no separate analysis of the results of the subjects with individual cancer types, not medicinal studies)

Inclusion from reference lists (1)

Exclusion due to low quality (2)

Full texts in review (9)

Figure 1 Flow chart of study selection process.

The review shows that the willingness to participate in the theoretical scenarios was considerably higher (58\%; range: $25-75 \%)[11,13,16]$ than in studies that were actually, or yet to be, conducted (27\%; range: $1.5-55 \%$ ) [12,14,15,17-19]. High willingness to participate in hypothetical scenarios is also seen in other studies [26-28]. Two studies collected their data retrospectively $[12,19]$, with the risk of recall bias in the results. Two other studies counteracted this bias by collecting would- be participants' relevant reasons immediately after consent or rejection of participating in their respective study $[15,18]$. This procedure could also prevent such distortion in future studies.

A limitation of this review concerns its ten-year time frame. Although more full texts might have been included if our criteria allowed older investigations, the primary goal of this review was to identify current studies; we therefore restricted this study to the past decade. 
Table 3 Methodological descriptions of the studies ( $N=9$ )

\begin{tabular}{|c|c|c|c|c|c|c|}
\hline Reference & Country & Objective/Question & Design & Method & Participants & $\begin{array}{l}\text { Data } \\
\text { analysis }\end{array}$ \\
\hline $\begin{array}{l}\text { Altschuler \& } \\
\text { Somkin } \\
2005[19]\end{array}$ & USA & $\begin{array}{l}\text { Why did women who initially showed } \\
\text { interest in participating in the STAR trial } \\
\text { make different decisions about whether } \\
\text { to participate or not participate? } \\
\text { (tamoxifen or raloxifene) }\end{array}$ & $\begin{array}{l}\text { Qualitative } \\
\text { chemo- } \\
\text { prevention } \\
\text { study }\end{array}$ & $\begin{array}{l}\text { Half-structured } \\
\text { deep interviews }\end{array}$ & $\begin{array}{l}51 \text { post-menopausal women } \\
\text { with high breast cancer risk }(28 \\
\text { participants and } 23 \text { non- } \\
\text { participants) }\end{array}$ & $\begin{array}{l}\text { Grounded } \\
\text { theory }\end{array}$ \\
\hline $\begin{array}{l}\text { Ellis et al } \\
2002[11]\end{array}$ & Canada & $\begin{array}{l}\text { Evaluation of information brochure, } \\
\text { regarding theoretical willingness to } \\
\text { participate in a 6-month clinical trial for } \\
\text { breast cancer treatment (Tamoxifen } \\
\text { alone, chemotherapy alone or } \\
\text { combined) }\end{array}$ & $\begin{array}{l}\text { Quantitative } \\
\text { before-after- } \\
\text { study }\end{array}$ & $\begin{array}{l}\text { Questionnaires } \\
\text { closed answers }\end{array}$ & $\begin{array}{l}\text { Before: } 83 \text { women with early } \\
\text { invasive breast cancer } \\
\text { After: } 67 \text { women }\end{array}$ & $\begin{array}{l}\text { Descriptive } \\
\text { statistics }\end{array}$ \\
\hline $\begin{array}{l}\text { Houlihan et } \\
\text { al } 2010[12]\end{array}$ & USA & $\begin{array}{l}\text { Investigation of factors influencing } \\
\text { women's decision to participate in } \\
\text { breast cancer prevention trial (tamoxifen, } \\
\text { raloxifene). }\end{array}$ & $\begin{array}{l}\text { Quantitative } \\
\text { case-control } \\
\text { study }\end{array}$ & $\begin{array}{l}\text { Questionnaires } \\
\text { through mail }\end{array}$ & $\begin{array}{l}\text { Of } 242 \text { post-menopausal } \\
\text { women, } 81 \text { participated }\end{array}$ & $\begin{array}{l}\text { Logistic } \\
\text { regression } \\
\text { model }\end{array}$ \\
\hline $\begin{array}{l}\text { Kim et al } \\
2004[13]\end{array}$ & USA & $\begin{array}{l}\text { When financial conflicts of interest were } \\
\text { stated on consent forms, which } \\
\text { respondents refused to participate in a } \\
\text { study using a new medication solely on } \\
\text { the basis of these conflicts of interest? }\end{array}$ & $\begin{array}{l}\text { Quantitative } \\
\text { study }\end{array}$ & $\begin{array}{l}\text { Internet } \\
\text { questionnaires; } \\
\text { closed answers }\end{array}$ & $\begin{array}{l}1006 \text { female breast cancer } \\
\text { patients }\end{array}$ & $\begin{array}{l}\text { Descriptive } \\
\text { statistics }\end{array}$ \\
\hline $\begin{array}{l}\text { Lemieux et } \\
\text { al } 2008[14]\end{array}$ & Canada & $\begin{array}{l}\text { Identifying barriers in the study } \\
\text { protocols, with respect to the low } \\
\text { recruitment rates in clinical breast cancer } \\
\text { trials, 1997-2002. }\end{array}$ & $\begin{array}{l}\text { Quantitative } \\
\text { study }\end{array}$ & $\begin{array}{l}\text { Questionnaires; } \\
\text { closed answers }\end{array}$ & $\begin{array}{l}616 \text { women participated in } \\
\text { studies of Phase III (or II+ III) } \\
\text { and } 72 \text { in studies of Phase II (or } \\
\text { I+II). }\end{array}$ & $\begin{array}{l}\text { Multivariate } \\
\text { analysis }\end{array}$ \\
\hline $\begin{array}{l}\text { Loehberg et } \\
\text { al } 2010[15]\end{array}$ & Germany & $\begin{array}{l}\text { Identification of characteristics of } \\
\text { women who wanted to receive } \\
\text { information about a Phase II } \\
\text { chemoprevention study. }\end{array}$ & $\begin{array}{l}\text { Quantitative, } \\
\text { multi- } \\
\text { centered } \\
\text { study }\end{array}$ & Questionnaires & $\begin{array}{l}202 \text { women of } 446 \text { wanted to } \\
\text { receive further information } \\
\text { about the risk of breast cancer; } \\
3 \text { women decided to } \\
\text { participate. }\end{array}$ & $\begin{array}{l}\text { Descriptive } \\
\text { statistics }\end{array}$ \\
\hline $\begin{array}{l}\text { Mancini et } \\
\text { al } 2007 \text { [16] }\end{array}$ & France & $\begin{array}{l}\text { Identification of preferences in decision- } \\
\text { making processes in relation to } \\
\text { participation in another clinical drug } \\
\text { trial. }\end{array}$ & $\begin{array}{l}\text { Quantitative, } \\
\text { prospective } \\
\text { cohort study }\end{array}$ & Questionnaires & $\begin{array}{l}\text { Of } 455 \text { women } 267 \text { were invited } \\
\text { to the study; of these } 201 \\
\text { agreed to participate and } 66 \\
\text { declined. }\end{array}$ & $\begin{array}{l}\text { Descriptive } \\
\text { statistics and } \\
\text { multivariate } \\
\text { analysis }\end{array}$ \\
\hline $\begin{array}{l}\text { Mandelblatt } \\
\text { et al } 2005 \\
{[17]}\end{array}$ & USA & $\begin{array}{l}\text { Effectiveness of a brief consultation and } \\
\text { an informational brochure compared } \\
\text { with use of brochure only in recruitment } \\
\text { for a breast cancer prevention study. } \\
\text { (tamoxifen and raloxifene) }\end{array}$ & $\begin{array}{l}\text { Quantitative, } \\
\text { simple } \\
\text { randomized } \\
\text { controlled } \\
\text { study }\end{array}$ & Questionnaires & $\begin{array}{l}232 \text { of } 450 \text { women participated } \\
\text { in consultation +brochure- } \\
\text { group; } 218 \text { of } 450 \text { in the } \\
\text { brochure-only-group }\end{array}$ & $\begin{array}{l}\text { Descriptive } \\
\text { statistics and } \\
\text { logistical } \\
\text { regression } \\
\text { model }\end{array}$ \\
\hline $\begin{array}{l}\text { Rondanina } \\
\text { et al } 2008 \\
{[18]}\end{array}$ & Italy & $\begin{array}{l}\text { Socio-demographic, health-related and } \\
\text { psychological factors influencing } \\
\text { decision to participate or not in a five- } \\
\text { year hormone replacement therapy. } \\
\text { (HRT-Phase III, low-dose tamoxifen) }\end{array}$ & $\begin{array}{l}\text { Quantitative } \\
\text { study }\end{array}$ & $\begin{array}{l}\text { Questionnaires } \\
\text { through mail }\end{array}$ & $\begin{array}{l}496 \text { of } 1457 \text { women } \\
\text { participated in the HET-study }\end{array}$ & $\begin{array}{l}\text { Descriptive } \\
\text { statistics and } \\
\text { multivariate } \\
\text { analysis }\end{array}$ \\
\hline
\end{tabular}

The strengths of this review include its use of an extensive assessment scheme, allowing comprehensive quality evaluation of the respective articles, using consistent criteria. This scheme also could function as a kind of checklist, thus reducing the probability of forgetting any items in the assessment. Another strong point was that six databases were searched, allowing wide coverage of possible publications, as a result, of the articles gleaned from the references of all the full texts, only one was found that had not been part of the original database literature research. Inclusion of only high-quality studies is a further strength, as all studies had to show a high quality, of at least $75 \%$, to be included in this review. Two studies did not meet this requirement and were therefore not included in the results $[29,30]$.

Physicians' viewpoints as to why women with breast cancer or breast cancer risk choose or decline to participate in medication studies is being researched, both with regard to general cancers [31] and breast cancer $[24,32]$, but not specifically with medication studies.

In sum, this review shows that the reasons for participation/non-participation in medication studies are multifactorial. Moreover, while factors affecting patient participation in medication studies are obviously useful to know in planning and realizing future investigations, few such insights are currently available, apparently due 
Table 4 Quality assessment according to AHFMR $2004(\mathrm{~N}=1)$

\begin{tabular}{|c|c|c|}
\hline Criteria & Assessment* & Remarks \\
\hline \multicolumn{3}{|c|}{ Altschuler \& Somkin 2005 [19] (Score $\left.=0.80^{* *}\right)$} \\
\hline $\begin{array}{l}\text { Research question(s)/ } \\
\text { Objective(s) }\end{array}$ & Yes & Described clearly and evident throughout the text \\
\hline Study design & Partially & Not explicitly named; inconsistencies in subsequent data collection not evident \\
\hline Study context & Yes & Setting is described \\
\hline $\begin{array}{l}\text { (Theoretical) frame of } \\
\text { reference }\end{array}$ & Partially & Study objective does not completely follow the knowledge that is depicted in the introduction \\
\hline Sampling & Partially & $\begin{array}{l}\text { Described and reproducible; random sampling was performed until theoretical data saturation was reached; } \\
\text { consent of women was obtained before the interviews began. Duration of study not mentioned. }\end{array}$ \\
\hline Data collection & Yes & Reproducible \\
\hline Data analysis & Yes & Categories, codes, and memos described; categories listed explicitly \\
\hline Reliability & Yes & $\begin{array}{l}\text { Second author verified formation of categories/assignment of codes by the first author; if there were } \\
\text { discrepancies in the codes, they went back to the original material and found consensus }\end{array}$ \\
\hline Conclusions & Yes & Results discussed; results of other studies are drawn upon as comparison \\
\hline Reflexion & Partially & $\begin{array}{l}\text { Possible influence of financial compensation were not reflected; recall bias listed as possible weakness of } \\
\text { the study }\end{array}$ \\
\hline
\end{tabular}

*Possible categories: yes, partially, no, not applicable

** Ascertainment according to AHFMR 2004 (p. 20) = ((number "yes" * 2) + (number "partially" * 1))/20

Table 5 Quality assessment according to AHFMR 2004 ( $\mathrm{N}=8$ )

\begin{tabular}{|c|c|c|}
\hline Criteria & Assessment* & Remarks \\
\hline \multicolumn{3}{|c|}{ Ellis et al 2002 [11] (Score $\left.=0.71^{* *}\right)$} \\
\hline $\begin{array}{l}\text { Research question(s)/ } \\
\text { Objective(s) }\end{array}$ & Yes & At the beginning of the introduction; contains dependent/independent variables, including population \\
\hline Study design & Partially & Not explicitly described, no inconsistencies in the subsequent data collection \\
\hline Sampling & Yes & Described, exclusion criteria mentioned; written consent obtained in each case \\
\hline Sample characteristics & Yes & Basic information given and depicted in tables \\
\hline Randomization & Partially & Randomization performed; exact process of randomization not described \\
\hline Blinding: Researchers & n.a. & Not possible \\
\hline Blinding: Participants & n.a. & Not possible \\
\hline Data collection & Partially & Categories of questionnaires given \\
\hline Sample size & Partially & Power analysis performed; no information about low response rate of second questionnaire \\
\hline Data analysis & Partially & Regression appropriate; no indication regarding the characteristics of participating/non-participating women \\
\hline Variance estimate & Yes & Confidence intervals and ranges indicated \\
\hline $\begin{array}{l}\text { Confounding factor } \\
\text { control }\end{array}$ & Partially & Control at analysis level with multivariate model, but no attempt to standardize the physician's consultation \\
\hline Result depiction & Partially & Described in the text; the secondary result (change of knowledge) was not depicted graphically/in a table. \\
\hline Conclusions & Yes & Relevant results are discussed and compared with other studies \\
\hline \multicolumn{3}{|c|}{ Houlihan et al $2010[12]\left(\right.$ Score $\left.=0.86^{* *}\right)$} \\
\hline $\begin{array}{l}\text { Research question(s)/ } \\
\text { Objective(s) }\end{array}$ & Yes & Listed \\
\hline Study design & Yes & Stated \\
\hline Sampling & Partially & Inclusion criteria mentioned, procedure not described \\
\hline Sample characteristics & Partially & $\begin{array}{l}\text { Information only regarding city and ethnic group given; average age of the women only in Discussion } \\
\text { section (but without standard deviation); other basic data are not available }\end{array}$ \\
\hline Randomization & n.a. & Not possible \\
\hline Blinding: Researchers & n.a. & Not possible \\
\hline Blinding: Participants & n.a. & Not possible \\
\hline Data collection & Partially & Reproducible on a limited basis \\
\hline Sample size & Yes & $\begin{array}{l}\text { No power or variance analysis given; no problems with multiple tests described and significant values were } \\
\text { obtained }\end{array}$ \\
\hline Data analysis & Yes & Described \\
\hline
\end{tabular}


Table 5 Quality assessment according to AHFMR $2004(\mathbf{N}=8)$ (Continued)

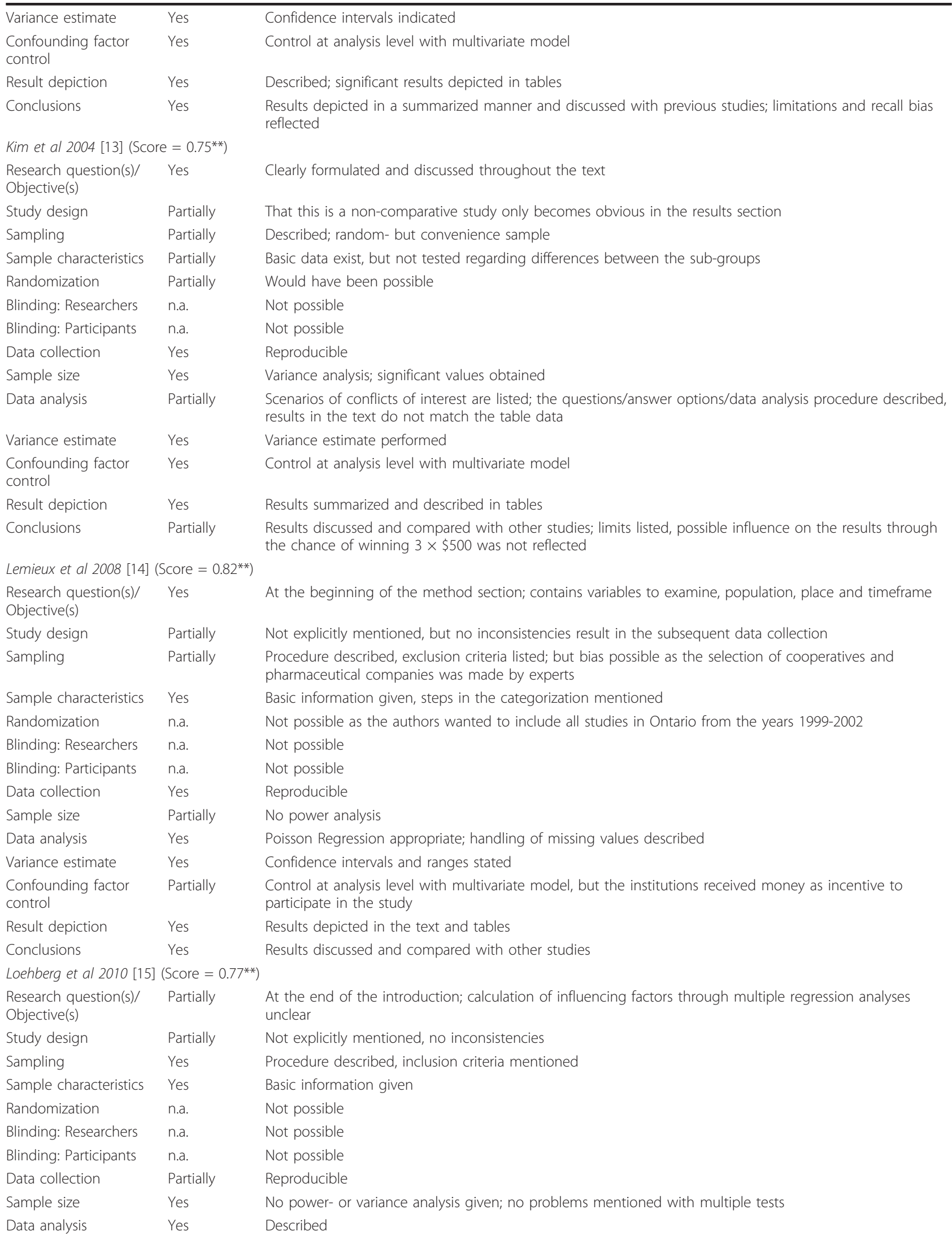


Table 5 Quality assessment according to AHFMR $2004(\mathbf{N}=8)$ (Continued)

\begin{tabular}{|c|c|c|}
\hline Variance estimate & Yes & Confidence intervals and distribution indicated \\
\hline $\begin{array}{l}\text { Confounding factor } \\
\text { control }\end{array}$ & Yes & Analysis of sub-groups conducted \\
\hline Result depiction & Partially & $\begin{array}{l}\text { Results depicted in the text and tables do not all follow the objective of the article, but seem to be } \\
\text { appropriate in general. }\end{array}$ \\
\hline Conclusions & Partially & $\begin{array}{l}\text { Results discussed and compared with other studies; no critical reflection that the information could possibly } \\
\text { influence the number of participants }\end{array}$ \\
\hline \multicolumn{3}{|c|}{ Mancini et al $2007[16]\left(\right.$ Score $\left.=1.00^{* *}\right)$} \\
\hline $\begin{array}{l}\text { Research question(s)/ } \\
\text { Objective(s) }\end{array}$ & Yes & Described precisely \\
\hline Study design & Yes & Described and appropriate \\
\hline Sampling & Yes & Procedure described; inclusion criteria mentioned; consent forms collected \\
\hline Sample characteristics & Yes & Basic information on the women and sub-groups given; \\
\hline Randomization & n.a. & Not possible \\
\hline Blinding: Researchers & n.a. & Not possible \\
\hline Blinding: Participants & n.a. & Not possible \\
\hline Data collection & Yes & Reproducible \\
\hline Sample size & Yes & No power- or variance analysis, sample size seems to be sufficiently large \\
\hline Data analysis & Yes & $\begin{array}{l}\text { Logistical regression analysis appropriate, individual tests within the framework of descriptive statistics } \\
\text { conducted; significance level mentioned }\end{array}$ \\
\hline Variance estimate & Yes & Confidence intervals and standard deviations given \\
\hline $\begin{array}{l}\text { Confounding factor } \\
\text { control }\end{array}$ & Yes & Control at analysis level with multivariate model \\
\hline Result depiction & Yes & $\begin{array}{l}\text { Results of regression analysis are listed in the text and table; not all significant results of the comparisons } \\
\text { within the framework of descriptive statistics were also described in the text, but no inconsistencies result }\end{array}$ \\
\hline Conclusions & Yes & Results discussed and compared with other studies \\
\hline \multicolumn{3}{|c|}{ Mandelblatt et al 2005 [17] (Score $\left.=0.79^{* *}\right)$} \\
\hline $\begin{array}{l}\text { Research question(s)/ } \\
\text { Objective(s) }\end{array}$ & Partially & $\begin{array}{l}\text { Described in the abstract, formulation of objective in the text fails to mention the investigation of two } \\
\text { interventions }\end{array}$ \\
\hline Study design & Yes & Described and appropriate \\
\hline Sampling & Yes & Procedure described; inclusion criteria mentioned; consent forms collected \\
\hline Sample characteristics & Yes & Basic information on the women and sub-groups given \\
\hline Randomization & Yes & Randomization performed; procedure described \\
\hline Blinding: Researchers & n.a. & Not possible \\
\hline Blinding: Participants & n.a. & Not possible \\
\hline Data collection & Yes & Reproducible \\
\hline Sample size & Yes & Not obvious whether a power analysis was conducted later; the sample size seems to be sufficient \\
\hline Data analysis & Partially & $\begin{array}{l}\text { Logistical regression analysis appropriate, tests conducted within the framework of descriptive statistic } \\
\text { analysis are not mentioned; handling of missing values described; significance level not given }\end{array}$ \\
\hline Variance estimate & Yes & Confidence intervals, standard deviations and range given \\
\hline $\begin{array}{l}\text { Confounding factor } \\
\text { control }\end{array}$ & Partially & $\begin{array}{l}\text { Control at analysis level with multivariate model; but in asking the control group, the same standardized } \\
\text { questionnaire as in the intervention group was used }\end{array}$ \\
\hline Result depiction & Partially & $\begin{array}{l}\text { Secondary results depicted in the text and tables; but the primary result is not mentioned in the text, it is } \\
\text { only listed in the table; recording of influencing factors not conducted for both interventions. Differences } \\
\text { regarding the objective breast cancer risk between those women who consented to participation in the } \\
\text { medication study and those who refused participation were not pointed out. The text only lists percentages } \\
\text { and no absolute numbers; consequently, readers have to infer from the tables how many women in total } \\
\text { participated in the data collection, and subsequently in the medication study. }\end{array}$ \\
\hline Conclusions & Partially & Results discussed but only partially compared with other studies \\
\hline \multicolumn{3}{|c|}{ Randonina et al 2008 [18] (Score $\left.=0.91^{* *}\right)$} \\
\hline $\begin{array}{l}\text { Research question(s)/ } \\
\text { Objective(s) }\end{array}$ & Yes & $\begin{array}{l}\text { Appears in the middle of the method section, primary and secondary results are mentioned at the end of } \\
\text { the introduction }\end{array}$ \\
\hline Study design & Partially & Not mentioned explicitly for this collection process, only the design of the medication study is described \\
\hline Sampling & Yes & Procedure described; including criteria mentioned; consent forms collected \\
\hline Sample characteristics & Yes & Basic information on the women and sub-groups given \\
\hline Randomization & n.a. & Not possible \\
\hline
\end{tabular}




\begin{tabular}{|c|c|c|}
\hline Blinding: Researchers & n.a. & Not possible \\
\hline Blinding: Participants & n.a. & Not possible \\
\hline Data collection & Yes & Reproducible \\
\hline Sample size & Yes & Power analysis given \\
\hline Data analysis & Yes & $\begin{array}{l}\text { Analysis appropriate and apparent from the objective; handling of missing values described; significance } \\
\text { level given }\end{array}$ \\
\hline Variance estimate & Yes & Confidence intervals, standard deviations and ranges given \\
\hline $\begin{array}{l}\text { Confounding factor } \\
\text { control }\end{array}$ & Yes & $\begin{array}{l}\text { Control at analysis level with multivariate model; also, control regarding age distribution based on low } \\
\text { response rate for questionnaires; furthermore, an attempt was made to standardize the preceding } \\
\text { consultation session }\end{array}$ \\
\hline Result depiction & Partially & $\begin{array}{l}\text { Results depicted in the text and tables and correspond with each other; but results of the regression } \\
\text { analysis are interpreted in the text as "in connection with" and not as "influence" - the interpretation in the } \\
\text { framework of the remark in the table is again depicted correctly }\end{array}$ \\
\hline Conclusions & Yes & Results discussed and compared with other studies \\
\hline
\end{tabular}

* Possible categories: yes, partially, no, not applicable

** Ascertainment according to AHFMR 2004 (p. 14) = ((number "yes" * 2) + (number "partially"” * 1))/(28 - (number "n.a." *2))

to the small number of relevant studies; further quantitative and qualitative research is needed.

\section{Author details}

${ }^{1}$ Medical University Graz, Auenbruggerplatz 14, 8036 Graz, Austria. ${ }^{2}$ Medical University Graz, Gender Medicine \& EZA, Graz, Austria.

\section{Authors' contributions}

All authors carried out the literature research, evaluated texts separately and discussed the results together. All authors drafted the manuscript and approved the final version.

\section{Competing interests}

The authors declare that they have no competing interests.

Received: 13 September 2011 Accepted: 11 March 2012

Published: 11 March 2012

\section{References}

1. Murthy VH, Krumholz HM, Gross CP: Participation in cancer clinical trials: race-, sex-, and age-based disparities. J Amer Med Assoc 2004, 291(22):2720-2726.

2. NCRN. Peninsula Cancer Research Network: Annual Progress Report. 2004

3. Carlin JB, Doyle LW: Statistics for clinicians: sample size. J Paediatr Child H 2002, 38(3):300-304.

4. Richards L: Handling Qualitative Data. A Practical Guide. 2 edition. SAGE Publications: London; 2009, ISBN.

5. McDonald AM, Knight RC, Campbell MK, Entwistle VA, Grant AM, Cook JA, Elbourne DR, Francis D, Garcia J, Roberts I, Snowdon C: What influences recruitment to randomised controlled trials? A review of trials funded by two UK funding agencies. Trials 2006, 7:9.

6. Fayter D, McDaid C, Ritchie G, Stirk L, Eastwood A: Systematic review of barriers, modifiers, and benefits involved in participation in cancer clinical trials. York: University of York, Centre for Reviews and Dissemination; 2006 [http://www.york.ac.uk/inst/crd/CRD_Reports/ crdreport31.pdf].

7. Mills EJ, Seely D, Rachlis B, Griffith L, Wu P, Wilson K, Ellis P, Wright JR: Barriers to participation in clinical trials of cancer: a meta-analysis and systematic review of patient-reported factors. Lancet Oncol 2006, 7(2):141-148.

8. Townsley CA, Selby R, Siu LL: Systematic review of barriers to the recruitment of older patients with cancer onto clinical trials. J Clin Oncol 2005, 23(13):3112-3124.

9. Fasching PA, Lux MP, Helm G, Beckmann MW: Medikamentöse Therapie von Frauen mit primären Mammakarzinom. Ein zentraler Baustein der Behandlung. [Medicamentous Therapy of Women with Primary Breast
Carcinoma. A Central Element of the Treatment.]. Klinikarzt 2004, 33(11):324-330.

10. AHFMR: Standard Quality Assessment Criteria for Evaluating Primary Research Papers from a Variety of Fields. HTA Initiative 2004, 02(13).

11. Ellis PM, Butow PN, Tattersall MHN: Informing breast cancer patients about clinical trials: a randomized clinical trial of an educational booklet. Ann Oncol 2002, 13(9):1414-1423.

12. Houlihan RH, Kennedy MH, Kulesher RR, Lemon SC, Wickerham DE, Hsieh CC, Altieri DC: Identification of accrual barriers onto breast cancer prevention clinical trials: a case-control study. Cancer 2010, 116(15):3569-3576

13. Kim SYH, Millard RW, Nisbet P, Cox C, Caine ED: Potential research participants' views regarding researcher and institutional financial conflicts of interest. J Med Ethics 2004, 30(1):73-79.

14. Lemieux J, Goodwin PJ, Pritchard KI, Gelmon KA, Bordeleau L, Duchesne D, Camden S, Speers CH: Identification of cancer care and protocol characteristics associated with recruitment in breast cancer clinical trials. J Clin Oncol 2008, 26(27):4458-4465.

15. Loehberg CR, Jud SM, Haeberle L, Heusinger K, Dilbat G, Hein H, Rauh C, Dall P, Rix N, Heinrich S, Buchholz S, Lex B, Reichler B, Adamietz B, SchulzWendtland R, Beckmann M, Fasching P: Breast cancer risk assessment in a mammography screening program and participation in the IBIS-II chemoprevention trial. Breast Cancer Res Tr 2010, 121(1):101-110.

16. Mancini J, Genève J, Dalenc F, Genre D, Monnier A, Kerbrat P, Largillier R, Serin D, Rios M, Roché H, Jimenez M, Tarpin C, Reynier CJ: Decision-making and breast cancer clinical trials: how experience challenges attitudes. Contemp Clin Trials 2007, 28(6):684-694.

17. Mandelblatt J, Kaufman E, Sheppard VB, Pomeroy J, Kavanaugh J, Canar J, Pallandre L, Cullen J, Huerta E: Breast cancer prevention in community clinics: will low-income Latina patients participate in clinical trials? Prev Med 2005, 40(6):611-618.

18. Rondanina G, Puntoni M, Severi G, Varricchio C, Zunino A, Feroce I, Bonanni B, Decensi A: Psychological and clinical factors implicated in decision making about a trial of low-dose tamoxifen in hormone replacement therapy users. J Clin Oncol 2008, 26(9):1537-1543.

19. Altschuler A, Somkin CP: Women's decision making about whether or not to use breast cancer chemoprevention. Women Health 2005, 41(2):81-95.

20. Gail MH, Brinton LA, Byar DP, Corle DK, Green SB, Schairer C, Mulvihill J. Projecting individualized probabilities of developing breast cancer for white females who are being examined annually. I Nat/ Cancer / 1989, 81:1879-1886.

21. Andersen MR, Peacock S, Nelson J, Wilson S, Mclntosh M, Drescher C, Urban N: Worry about ovarian cancer risk and use of ovarian cancer screening by women at risk for ovarian cancer. Gynecol Oncol 2002, 85(1):3-8.

22. Diefenbach MA, Miller SM, Daly MB: Specific worry about breast cancer predicts mammography Use in women at risk for breast and ovarian cancer. [Report]. Health Psychol 1999, 18(5):532-536. 
23. Bjorvatn C, Eide GE, Hanestad BR, Oyen N, Havik OE, Carlsson A, Berglund G: Risk perception, worry and satisfaction related to genetic counseling for hereditary cancer. Genet Couns 2007, 16(2):211-222.

24. Nguyen $\Pi$, Somkin CP, Ma Y: Participation of Asian-American women in cancer chemoprevention research: physician perspectives. Cancer 2005, 104(12 Suppl):3006-3014

25. Ellis PM: Attitudes towards and participation in randomised clinical trials in oncology: a review of the literature. Ann Oncol 2000, 11(8):939-945.

26. Fallowfield $\sqcup$, Jenkins V, Brennan C, Sawtell M, Moynihan C, Souhami RL: Attitudes of patients to randomised clinical trials of cancer therapy. Eur $J$ Cancer 1998, 34(10):1554-1559.

27. Jenkins V, Farewell D, Batt L, Maughan T, Branston L, Langridge C, Parlour L, Farewell V, Fallowfield L: The attitudes of 1066 patients with cancer towards participation in randomised clinical trials. Brit J Cancer 2010, 103(12):1801-1807.

28. Schain WS: Barriers to clinical trials. Part II: knowledge and attitudes of potential participants. Cancer 1994, 74(9 Suppl):2666-2671.

29. Maisonneuve A, Huiart L, Rabayrol L, Horsman D, Didelot R, Sobol H, Eisinger F: Acceptability of cancer chemoprevention trials: impact of the design. Int J Med Sci 2008, 5(5):244-247.

30. Linden HM, Reisch LM, Hart A, Harrington M, Nakano C, Jackson JC, Elmore JG: Attitudes toward participation in breast cancer randomized clinical trials in the African American community: a focus group study. Cancer Nurs 2007, 30(4):261-269.

31. Paskett ED, Cooper MR, Stark N, Ricketts TC, Tropman S, Hatzell T, Aldrich T, Atkins J: Clinical trial enrollment of rural patients with cancer. Cancer Pract 2002, 10(1):28-35.

32. Kornblith AB, Kemeny M, Peterson BL, Wheeler J, Crawford J, Bartlett N, Fleming G, Graziano S, Muss H, Cohen HJ: Survey of oncologists' perceptions of barriers to accrual of older patients with breast carcinoma to clinical trials. Cancer 2002, 95(5):989-996.

\section{Pre-publication history}

The pre-publication history for this paper can be accessed here: http://www.biomedcentral.com/1471-2288/12/25/prepub

\section{doi:10.1186/1471-2288-12-25}

Cite this article as: Luschin et al:: Reasons for and against participation in studies of medicinal therapies for women with breast cancer: a debate. BMC Medical Research Methodology 2012 12:25.

\section{Submit your next manuscript to BioMed Central and take full advantage of:}

- Convenient online submission

- Thorough peer review

- No space constraints or color figure charges

- Immediate publication on acceptance

- Inclusion in PubMed, CAS, Scopus and Google Scholar

- Research which is freely available for redistribution

Submit your manuscript at www.biomedcentral.com/submit
C Biomed Central 